\title{
[ Translating Cultures in Museums: When not Only Words, but People, are Translated ]
}

\section{Alessandra Ficarra}

Università degli Studi della Calabria, Italy

[Abstract] Museums possess, represent and interpret others' culture, raising important questions on ownership and the authority of their conduct. The act of translating cultures is one of the prime modes through which history is rewritten and knowledge is constructed: through a selected representation of a given culture - its translation, indeed - museums give their version of the past, commemorating what is chosen to be commemorated. Museums construct and propose spaces of meanings in which other cultures and their stories are intelligible to visitors. However, it is time to capsize the interpretative perspective, and let the narrated become the narrator.

[Keywords] translation; culture; ethnographic museums; commemorative museums; slavery; rewriting history 
The relationship between word and world is among the most intricate subjects in cultural studies, where word encompasses all forms of textualized expression and world encompasses all forms of organization of life. This conceptual development generates the metaphor of culture as translation, which evokes the connection between culture and language. Language is perhaps the first element which is used to identify a given culture but language itself, instead of being a mere part of a culture, is also a vehicle which reflects some cultural specificities. Culture and language, therefore, are two independent but closely linked systems.

Members of a particular culture are constantly influenced by their mental representations: this influence is expressed mostly through language, used as communication between members of the same or different socio-cultural groups. Language, moreover, is part of the prime knowledge acquired by any individual in her very first stage of life, and it is the prime means which ensures that this knowledge passes on from generation to generation. Hence derives the intimate connection between language and culture, which becomes stronger on the level of semantics, where the vocabulary of a given language reflects the culture of its speakers (Appadurai 51). Language, however, is also the means by which other cultures are understood: when a text is translated, it is reproduced in another language. The task of the translator is to keep the meaning 'equivalent'. Equivalence is the major dilemma of the translator: the new text - the Target Text - should be equivalent not only to the source - the Source Text - but it should have an equivalent function in the Target Culture as well. Cultural knowledge, thus, has been recognized as indispensable for translation.

According to the postcolonial theorist Homi Bhabha, not only is translation a movement from source to target, but it is also located in a "third space" between the two, where the negotiation of conflicts arising from cultural difference occurs (5). The image of movement remains inevitably embedded in the concept of translation: etymologically, the word translation means "carried from one place to another" (Miller 207) - something translated is transported across the borders between one language and another, or between one country and another, or between one culture and another. For this reason, it may be affirmed that what is translated is displaced, transported, even if it is a text read in its original language but by someone who belongs to a different culture; the translation then becomes a flow of interpretation. The idea of movement, however, is not the exclusive domain of translation: according to the American anthropologist James Clifford, culture too can be rethought in terms of movement. Clifford suggests interpreting culture and its science anthropology in terms of travel - thus questioning the classical rooted nature of culture, and opening up a completely new perspective of analysis. Not only do people move from one language to another, from one culture to another, but cultures themselves are traversed "by tourists, by oil pipelines, by Western commodities, by radio and television signals" (Clifford, Traveling Cultures 101).

Undoubtedly, especially in the context of post-colonialism and globalization, culture is coming to be understood as a continuous translational process. The notion of culture is shifting towards a new dynamic concept, "a practice of negotiating cultural dif- 
ferences" (Bachman-Medick 37), for which cultural anthropology should embrace a new translational approach: firstly, the new cultural anthropology should accept the current trends of globalization, migration and the networking of consumption; secondly, translation should be approached as a form of familiar life practice which becomes effective especially in the contexts of migration; thirdly, the new cultural anthropology should abandon its old dichotomy of $u$ s and them, and embrace the understanding of multiple, hybrid forms of cultural configurations and interconnections.

By taking up these three translational tasks, the new cultural anthropology advocates an innovative understanding of translation: the traditional hermeneutic claim can be replaced by a pragmatic attention to cultural networks. At the basis of this new approach to translation, there should be our awareness that these continuous, translational cultural flows pertain not only to goods, images and slogans, but also to people and identities. As Salman Rushdie has poetically asserted, "having been born across the world, we are translated men" (18-19).

Since anthropology is a science of cultural comparison, it works with terms and concepts such as kinship, power, social conflict, religion, hierarchy, and so on. The risk of describing indigenous conceptions within a Western-oriented system is always present. The critique raised by the Saudi-American anthropologist Asad against the viability of translating cultures through ethnography lies precisely in the existence of evident power relations between the parts involved. Although the aim of the ethnographer is to discover the indigenous point of view, Asad points out how the ethnographer nevertheless assumes an implicit authority to choose what has to be said and what does not. Consequently - and dangerously -, the translation of the other culture resulting from the perspective of a Western ivory tower takes up a powerful position in the practical world. Asad, however, does not blame ethnography for being the prime or unique evil in the delicate process of translating cultures: of course, there also exist other important forms of Western influence and domination - economic, military, intellectual. In fact, critical attention has to be addressed to the longstanding phenomenon of the cultural universalization of the Western world. The West, in the collective imagination, represents the modern, and the modern West has established itself as "a culture of Cultures" (Ingold 214). But if Western culture is a culture of cultures, then it is not on a par with the other cultures. In fact, an enormous conceptual discrepancy divides them: whereas the other cultures, multiple and historically unique, differ from one another in their traditions, Western culture does not bear any different tradition: it entails, by contrast, a condition that is completely opposed to the notion of the traditional - the condition of modernity.

It is beyond doubt, in fact, that the modern West represents for many the culmination of the development of intellectual faculties; and this certainty of intellectual supremacy has long led to the standardization of the world according to the Western canons of rationality, objectivity, and logic: in the past, Westerners justified the manipulation and abuse of millions of enslaved Africans with the formula 'civilization versus primitiveness'; today, satellite dishes crop up from villages of huts, pursuing the mission 'modernity versus tradition'. For centuries, African and African-descended populations 
had to endure the indignity of being narrated, represented and displayed by Westerners; Westerners spoke on their behalf innumerable times, depriving them of voice, thoughts, identity and history (Trouillot 1995). If the idea of Africa as a distinct place and race is an invention of European cartography and expansionism, then a Western-centric construction of African people as 'subordinate' is a perserverance of colonial racism (Bassil 2005). Today, movements promoting identity recognition for social and ethnic minorities are blossoming from North America (Black Lives Matter), to Brazil (Movimento Negro Unificado), to Portugal (Djass, Association of Afro-descendants). Through these movements, communities and minorities that were historically marginalized and silenced are now fighting to regain what Djamila Ribeiro calls lugar de fala (place of speech): such minorities are calling for a deeper analysis of identity construction, questioning and rewriting their history. In Africa, activists in various countries - such as Uganda and Nigeria - are calling on their governments to remove colonialists' names from streets. This is a phenomenon encompassing not only ethnic minorities, but minority categories in general: people with disabilities, women, LGBT+, and so forth - all those people who have suffered prejudice are now fighting to speak for themselves, as the protagonists of their own struggle and movement. It is a broad and international - yet still weak - process of de-silencing unheard voices and "decolonisation of the mind" (Hira 57).

The aforementioned questions of exclusion and inclusion, meaning, knowledge, truth and history are important areas in which post-museums are deeply involved. As it participates in the practice of translating cultures, cultural politics - implying the possibility of action and agency - is inevitably enmeshed in the dynamics of power. Museums represent an important battleground in which these dynamics occur - any visitor to any exhibit might question who has the power to name, to make visible, to represent the past and common sense, to "create official versions" and, by consequence, to legitimize meanings and values (Hooper-Greenhill 19). Museums definitively have the possibility to represent and rewrite history, which are central and delicate issues in cultural politics. Being museums, a prime symbol through which a society represents itself, they surely play a crucial role in cultural wars. Their collections and exhibitions have the power to crystallize not only cultures, but also history, science, identities - world-views. Any object displayed in a museum is surrounded by an aura of authenticity and credibility, so thick that it carries with it the tangibility of the absolute truth. Hence the notion of museums as "sites of persuasion" (Clifford, "Museums" 438): inside them, memory and meaning are created, social representations are constructed and public knowledge is produced.

Intriguingly, not only can museums rewrite history, but they also use controversial instruments to do it. It is well - and sadly - known, for instance, that a hugely large proportion of objects displayed in Western ethnographic collections arrived there in the wake of what were once known as colonialist adventures. Many of these objects that are preserved in museums are no longer visible in their countries of origin. Furthermore, many of them are sacred objects of some communities, for whom their public display would be deeply offensive. These are only some of the controversial problems related to the debate on ownership, authority and ethics - a considerable cultural war. As museums have the 
possibility to possess, (re)present and interpret others' material culture, their attitudes and conduct will always raise important questions on ownership and authority. Museum ethics, in fact, is one of the crucial debates of our time, to the extent that it has become a distinct field in Museum Studies. Since the cultural identity of a given community is often expressed and preserved in their objects and artefacts, it can be easily understood why the former Director of the Manchester Museum Tristram Besterman defined ethics as an expression of social responsibility, which regulates the relationships of the museum "not with things, but with people" (431).

Translating cultures represents one of the prime modes through which history is rewritten and knowledge is constructed. Simply said, through a selected representation of a given culture - its translation, indeed -, museums give their version of the past, or they commemorate something, or they substantiate national pride. Like ethnographies, museums construct and propose spaces of meanings in which other cultures are intelligible to visitors. But how is translation embedded in museums' practices and collections? First of all, if museums are considered in terms of translation, the museums' representation of cultures should be viewed as 'written' by the institution and then 'read' by (interpretive) visitors. Of course, such an analysis rejects the idea that objects are neutral and silent things - they do speak, and they speak more than one language. Everything about the collection has to be read - the ways objects are collected, why and how, and why only those particular objects are displayed. In her Museum Studies, Bettina Messias Carbonell identifies four tropes on which the rhetoric of museums relies: metaphor - i.e. objects stand for something other than themselves; metonymy - i.e. one single object is used to evoke a complex reality; synecdoche - i.e. one single object stands as a part for the larger whole; and irony - i.e. objects contradict themselves in the exhibition. Analogously, the textual approach adopted by the cultural theorist Mieke Bal involves reading and analyzing the object exposed like a text for its narrative structures and strategies: one might, for instance, consider the narrative strategies and voices implicit in the labels, the lights and the sounds of a given exhibition. Similarly, the sociologist Roger Silverstone has applied the idea of narrative to museums: he too invokes the concept of poetics, but referring to "the particularities of the museum as medium: with its role as story-teller, as myth maker, as imitator of reality" (143).

Understanding museums in terms of texts and narratives has the advantage of shaking down the aura of power associated with particular aspects and/or figures of museums that were once privileged and untouched - their buildings, staff, curators. All these components remain undoubtedly crucial; reading a museum through a textual approach suggests that they are all called into question. The visitor is therefore considered as a crucial participant in the process of meaning-making; in line with Barthes and Foucault, who rejected the idea that the author controls the meaning of a text - a text is the product and the producer of its own social, cultural and historical discourses.

Museums, however, have not always promoted and encouraged the idea that visitors can contribute to the construction of multiple meanings: from the Renaissance to the late eighteenth century, museums' representational modes did not offer enough space 
for reading and reflection. The Renaissance 'cabinets of curiosities' gave way to the memory space of the Enlightenment period. In the eighteenth century, museums were places that aimed at educating people, where art and historical civilization gained a chronology and a nation-state aspect. Thus, museums as colonial institutions - as suggested by Benedict Anderson - were able to create logos and symbols of national identity, turning living history into a series of dead artefacts. If nations were - or still are - emotional and cultural phenomena, museums have inevitably contributed to the creation of imagined political communities where people with shared origins and mutual interests could recognize themselves within the borders of that limited territory (Anderson).

In the nineteenth and twentieth century, the emergence of the discipline of anthropology contributed to the development of ethnological museums, which needed academic ethnographic expertise to select, comment on and interpret the findings of anthropologists and ethnographers. At the same time, museums reflected the colonial venture, claiming the otherness but also the intelligibility - and in many cases the inferiority - of the colonized lands. The Pitt Rivers Museum is an infamous example of a nineteenth-century ethnographic collection: with its evolutionary timeline from 'primitive' to 'modern' - i.e. from 'savage' to 'civilized' - it confirmed the racist claims of the time, legitimizing the colonial mission and offering a very specific political stance to the domestic audience.

However, the evolutionary arrangement was not the one that came to dominate Western museums: in the late nineteenth-century, geographical arrangement schemes developed as well, helping to create entities like Africa by means of their labelling strategies. Historical arrangements, by contrast, seemed to be disregarded, fostering a de-historicizing tendency which was strongly visible in the museums' labels and text panels: the ethnographic museums of the time usually used an unspecified past tense, excluding any sense of chronology and giving dates only within a century or even several centuries. Source texts' authors or translators were never named, and in most cases, artefacts' authors were defined as a tribe or even a location. In these ways, "smooth, unified entities" were created to underpin the ideology of racial domination (Sturge, 435). Displays of the time also included the diorama, i.e. a three-dimensional wax representation of animals - and, in the case of anthropological dioramas, people. It is not hard to imagine how, in anthropological dioramas, human beings were brought into a sort of zoological framework, which resulted in the creation of a sense of impersonality. Furthermore, by focusing on physical attributes and neglecting the thoughts, languages and actions of the real people they represented, museums implemented the objectification of the bodies on show, who - or which? - became specimens deprived of voice and individuality.

Another important aspect deserving attention is the way objects were displayed in ethnographic collections of the past. The objects and artefacts of a collection in fact represent the encounter between the creator and the collector. The fact that artefacts' authors were often omitted helped to conceal the colonial secret of how they came to be owned. The objects displayed in museums represented, and still represent, pieces of evidence attesting to the source culture. Their validity depends on their authenticity, which, 
in turn - and in terms of translation -, refers both to the genuineness of the source text and to the faithfulness of their translation, i.e. the curatorial representation. According to an ethnographic reading of the time, objects made by colonized people were supposed to be read in terms of their capacity to represent a way of life, and not as pieces of art sufficient to themselves. This crucial distinction between art and ethnography has been extensively discussed by Clifford. In his The Predicament of Culture, Clifford noted how, since the twentieth century, the collection of non-Western objects has been divided into two major categories: (scientific) cultural artefacts and (aesthetic) works of art. According to the Western collecting tendencies of the time, civilized art objects were produced by individuals, whereas primitive folkloristic (or ethnographic) objects were produced by a community. Thus, while art manages to speak for itself, ethnography needs to be explained - or translated. In this view, ethnographic objects were not unique, like art objects, but simply representative. Hence their need to be translated by means of labels and the experiences of the "translator of invisible truth" - the anthropologist (Clifford, Predicament 150).

Carol Duncan investigated the ways in which museums select and present their works of art, and how they communicate and affirm national ideas, values and social identities through them. The social anthropologist Wyatt MacGaffey further analyzed the way in which African art was translated in the European art-ethnography system. According to MacGaffey, in nineteenth-century museums the primitiveness of African art was used to construct the civilized identity of Europe. The representation of the colonies, their people and their objects as timeless, static and silent was a strategy to foster the self-representation of the colonizing society as historical, dynamic and active. MacGaffey thus proposed a notion of untranslatability - in his view, ethnographic museums of the time did not translate anything, "if by translation we mean to express in our own terms the significance of the objects to those who produced and used them" (249-50).

If modernist ethnographic museums have traditionally served to generate and foster colonialist identities, today's post-museums are largely rethinking the translation strategies used in collections. One of the new approaches in ethnographic collections is the actualization of the thick description proposed by Geertz. A thick description - evocative of Appiah's thick translation - refers to the elements which constitute the museum's verbal discourse - labelling, panels, booklets, catalogues and multimedia material. Labels, for instance, can "multiply voices" (Sturge 436). The labels of the gallery African Worlds at the Horniman Museum in London, for instance, include a commentary that can be read as a kind of translation of the artefact and even of the originating culture. The commentary includes a short text by one of the users or makers of the object, both personal and ethnographic - e.g. citing proverbs and describing uses - first in the relevant African language and then in English translation. The speaker - the translator, indeed - is named and visible in a photograph as well; even the compiler of the label is named. This strategy of quotation used by the Horniman Museum tends to disrupt the classical power balance of ethnographic museums: the multilingual text seems to reject Western categorizations and to give voice to the objects represented. This strategy perfectly embodies the 
great interpretative shift which has occurred in post-museums: whereas the nineteenth-century viewers thought about themselves as outside or above what was represented and what they were looking at, nowadays the viewers and their perceptions are seriously taken into account - not only are they invited to express their own perceptions, feelings and opinions on the way cultures are translated, but they are also asked to participate, in order to construct new meanings, in order to rewrite a fair history.

The practice of rewriting history is in fact a delicate issue which comes inevitably into being whenever a museum display is installed. Post-museums have to cope not only with a demanding audience, different cultures, and ethical responsibility, but also - and all too often - with a guilty past. A great number of commemorative museums, in fact, do exist because human rights violations occurred. Commemorative museums - such as slavery museums - are at the core of this new challenge. Since their emergence, museums have always been the symbol par excellence of conservation and preservation: as already mentioned, from the Renaissance period until a few decades ago, museums have acted mainly as repositories - art, culture and (natural) history were kept on their shelves, strengthening national pride or fostering the exoticism of remote places. The collection and exposition of material culture - items that enclose in their fixity the certainty of a past but also the pledge of immutability for the future - inevitably evoke in visitors the sensation of walking along a timeline: past, present and future converge, disciplined - or manipulated - by the complicated human act of memory.

The connection between collective memory and museums becomes stronger in the field of the memory of war. War memory has generally helped the creation of a nation's self-image. This nation's - or group's - memory is formed through a process which reflects the power structures within these groups, and which can be reflected in the imagery of memorials. A memorial, in fact, has the power to shape and consolidate collective memory. The 1980s - the decade in which the new museology emerged - witnessed a boom in the construction of war memorials throughout Europe and North America. In the same period, renewed controversies emerged over a number of aspects of the Second World War, including calls for apologies for the Japanese treatment of prisoners-of-war, and for the American use of nuclear weapons; Holocaust memorials and museums were constructed too, thus forging collective memories around national identities based on ideas of hegemony, technological supremacy, or victimhood. Since war is increasingly associated with imperialism, nationalism, patriotism - i.e. morally ambiguous concepts, which are very often correlated to the issues of racism, poverty and inequality - the creation of collective memory in museums remains a controversial subject, which continues to challenge present-day commemorative museums' curators.

In post-museums, memory takes on a new significance, and increasing attention is addressed to the individual, who is less viewed as a representative of a social group than understood as having her own precious, unique, distinctive perception of history: collective memory is constructed through autobiographical memories. In present-day commemorative museums, a new conceptual approach is reflected in the display of individual experiences and memories: history is narrated through an individual's recollections 
of flights and expulsions, pictures portraying the human body, autobiographical documents, and videos reconstructed to testify to personal experiences. All these new practices form the basis of present-day exhibitions, and they are important means for stimulating multiple interpretations, instead of a single imperative account of the past.

Nevertheless, personal and multiple interpretations of the past are not intended to create fragmented, individualized worlds: on the contrary, present-day innovative exhibitions do confront individual accounts, but with the purpose of creating a common ground. Historical and commemorative exhibitions in fact exist to restore a shared memory, a collective cultural identity. Memory is thus intertwined with another important concept, heritage. If until the French Revolution the term heritage was associated with a material property or possession that could be received by succession, and subsequently referred to immovable property and historical monuments, today what is called heritage includes not only artefacts, but also environments, traditions and activities, acquiring a more democratic spirit. Hence heritage as a sort of more inclusive mode of understanding and utilizing the past, which includes roots, identity, and the individual sense of belonging. Having a heritage is intrinsic to having an identity: the heritage affirms the right to exist in the present, and also the right to continue in the future. Heritage, moreover, plays a fundamental role in establishing and communicating a sense of cultural identity: museums can become places where heritage is manifested, creating opportunities for people to recall and reflect on a shared past - heritage, then, is a form of collective memory.

As memory-keepers, and as validated institutions, museums mediate the past, present and future. Giving material form to authorized versions of the past, these versions are in turn institutionalized as public memory. Moreover, every museum's presentation is always subjectively shaped, validating certain forms of cultural expression and affirming particular interpretations of the past. This process of memory production involves choices about what is remembered, but also what is forgotten. Nineteenth-and twentieth-century museums were implicated in the construction of identities and nation-building practices. Such practices have not necessarily been discarded in present-day museums.

But what are the subjects of most national histories? Sadly, the answer is: wars, conflicts, invasions of foreign lands, and plunder. What in the past was seen as a country's achievement and a sign of national triumph, today may be seen as a reason for regret. Let us consider colonialism: once the sign of national pride and domination, today it is a problematic and shameful heritage, with which national agendas have to come to terms. During the second half of the twentieth century and into the twenty-first, many nations have started to unearth the past, exhuming a past that is recognized to be meaningful in the present, even if contested for its shameful content. Plaques, information boards, monuments and - of course - museums are populating more and more cities, bearing witness to an unsettling past, and many minority cultural groups once ignored or discriminated against are now raising their voices to ensure that their identity is publicly and officially recognized.

In 1994, UNESCO launched the Slave Route Project, a huge international programme encouraging schools, archives and cultural institutions to promote research and 
the production of educational resources aimed at breaking the wall of silence which surrounded the biggest deportation in history: the transatlantic slave trade. In 1999, the District Six Museum in South Africa and eight other museums (from Asia to Europe, North and South America) founded the International Coalition of Sites of Conscience. In 2001, the French politician Christiane Taubira was the driving force of the Taubira Law, unanimously passed by the French parliament in May: it was the world's first law to declare the slave trade and the slavery crimes against humanity. This law also included an official commitment to enhance the importance of the history of slavery and of the transatlantic slave trade in French schools as well as in academic research. In 2007, Britain celebrated the bicentenary of the Abolition of the Slave Trade Act, beginning a challenging and continuous commitment to raise awareness of the history of the slave trade, its effects, and the existence of contemporary forms of slavery. The bicentenary was also an opportunity for the British to tackle inequality for people of African and Caribbean heritage in the UK, as well as to understand the difficulties faced by the African continent today. Throughout 2007, a great number of initiatives and activities were organized in various Commonwealth states, while a revised secondary curriculum was introduced in British schools for all children aged 11 to 14, which now covers the development of the slave trade, slavery in America, colonial rule in Africa, colonization and the links between slavery, the British empire and the industrial revolution.

These were only some of the crucial provisions adopted in the last twenty-five years by national and international law in order to preserve and share unsettling memories simultaneously, throughout the world, present-day commemorative museums started to exhume a blemished past, in order to make people understand its legacies in the present, and to prepare themselves for the future: from Africa (Robben Island Museum), to Asia (Tuol Sleng Genocide Museum), to the Americas (plantation house museums, People's Museum of Craft and Technology in Jamaica, Museu Digital da Memória Afro-Brasileira), to Europe (Nantes History Museum, Bordeaux's Museum of Aquitaine, the International Slavery Museum of Liverpool). Every culture has its own way to remember or forget the past: some cultures refuse to crystallize their identities in the role of the victims, some cultures refuse to admit they prospered from others' blood; some cultures unearth their shameful past slowly and quietly, as if to prevent too much dust from being raised, and others are facing up to a memory-monopoly or creating new and free spaces for sharing and commemoration. Sadly, many of the world's sites of memories are still spotted with inaccuracy, trivialization and fear: in this way they are perpetuating the hegemony of the dominant groups and reinforcing the silences in history.

Some other sites of memories are emerging only today, and only because they are being strongly claimed by minority voices: this is the case of Portugal, a country whose vessels carried around 5.8 million Africans into slavery for over four centuries. In 2017, campaigners from Djass, the above-mentioned Association of Afrodescendants, together with black activists and intellectuals, pointed to the urgent need for a Slavery Memorial. The monument, which should be inaugurated in the first trimester of 2021, will be the first Slavery Memorial in Portugal, and it will be erected in one of the most emblematic 
squares of Lisbon - right where the slave market existed. The long and heated debate which followed the Djass proposal to honour the enslaved ancestors with a memorial epitomizes the controversial spirit of a nation that has always strongly glorified its explorers and navigators and now seems ready to confront its colonial past and face up to its multiracial present.

A new emerging field of research is developing between memory studies and museum studies: authors like Silke Arnold-de Simine have investigated the role of museums during the so-called memory-boom and have explored the influence of memory discourse in museum cultures. When entering places of commemoration, visitors are asked to identify themselves with other people's suffering. However, it is hard to define to what extent a guilty past can be remembered collectively, both by those who consider themselves the descendants of victims and those who are labelled as descendants of perpetrators: monuments are erected all over the world, but there must be a difference in meaning and perception between a slavery museum in England and a slavery commemorative sculpture in Zanzibar. It is not only about culture, or identity, or languages and styles: it is about a process of elaborating conflicting historical experiences. The participation of a given visitor in the rite of commemoration does not mean that that visitor has the same meaning-experience as others, or as the curator or the artist intended. Ways of remembering and commemorating are influenced by the different significance every culture gives to history or to memory itself; these differently attributed meanings affect not only what is remembered, but also how this process is carried out. Obviously, what makes a difference in the way of remembering is not only cultural specificity, but also differences in access to sources or the availability of technologies and instruments.

After having visited the International Slavery Museum of Liverpool - hereafter ISM - important questions emerged: what is the perspective of enslaved Africans' descendants towards the ISM, the most award-winning slavery museum in the world? Can people of the African Diaspora recognize their own history and cultures in the way they are displayed by a European institution - or did the ISM translate them within an exclusively Western conceptual system? To investigate these questions, I tried to acquire an alternative reading of the ISM: a substantial number of students (90) from three different universities in Angola experienced the Museum in a virtual tour, and provided their response through free debate and the support of a handout.

The initial intention of the survey was to involve students from the universities in Luanda, who may have also visited the Museu da Escravatura, i.e. the Angolan national slavery museum. However, there were considerable difficulties at the outset in engaging with Angolan universities: after months spent in attempts to persuade a number of institutions - about ten - four agreed to participate: the Universities of Benguela Katyavala Bwila and Jean Piaget - respectively public and private -, the public University of Saurimo Lueji A. Nkonde, and the private University of Huambo Sol Nascente. There were many difficulties encountered in carrying out the fieldwork - the research topic, of course, was in itself delicate and controversial. For this or other reasons, unfortunately one of the four meetings failed to transpire: on the appointed date, nobody attended 
the session at the University of Sol Nascente. Nevertheless, these difficulties gave a new dimension to the study revealing some important social, cultural and political issues of present-day Angola.

The target groups for the fieldwork were Angolan students from the faculties of sociology and history - unfortunately, it was not possible to recruit students from the faculties of anthropology and languages. The meetings, however, were open to anyone. The participants virtually visited the ISM through a selection of pictures, videos and texts from the Liverpool exhibition, assembled in a PowerPoint presentation. The presentation tried to recreate the original atmosphere of the museum, and, exactly like the museum, it was divided into sections: each section was numbered, and each slide of the section, in turn, was identified with a letter. All the students participating in the meeting had a handout in which they were asked to write their age and course of study, while their name and surname were optional. The handouts gave a code for each slide, so that during the presentation, the students could tick and comment on the slides which affected them most. At the end of the handout an extra blank space was left for them to write down anything they wanted - a free comment, a poem, a drawing.

Considering the historical and emotional aspects involved, the three meetings were conducted in the shared national tongue - Portuguese - so that the participants could use their language to express their feelings and impressions freely on such a delicate subject. From the results of the survey, it can be evinced that the ISM received considerable appreciation and approval - only four students considered the ISM to be too 'European' in its modes and narrations or not representative enough for their culture. At the same time, however, in the responses of the participants the evident and shared desire, and necessity, to rewrite their own history could be read: putting together the preferences of all the students of the three universities, one cannot overlook the fact that $47 \%$ of the participants marked with an $\mathrm{X}$ the slide reporting the panel with Patrice Lumumba's quote: "Africa will write its own history, and it will be, to the north and to the south of the Sahara, a history of glory and dignity". As a matter of fact, although most of the students seemed to be generally pleased that the history of enslaved Africans was exhibited in a Museum, at the same time they felt deprived of a past and heritage that was brought to the West and that belongs to the West, since the latter controls its sources: "It's with pleasure that we Africans will rewrite our own history, but to do it it's necessary to facilitate the access to the sources, and most of them are in Europe. Thank you." (anonymous, 30 years, University of Benguela Katyavala Bwila).

Through this fieldwork, conducted in three Universities of Benguela and Saurimo, the Western visitors to the International Slavery Museum of Liverpool have been silenced, while the voices of an exclusively African audience have been finally listened to and contemplated (Ficarra 135). This sort of capsizing of interpretative perspective offered an alternative reading of the award-winning slavery museum in this British port city. Such an inversion of the meaning-making process appeared to be especially fitting, above all in the light of the museum's policy itself, whereby the Liverpool institution aims to be a vehicle of social change and a political campaigner in the field of human rights 
(Benjamin 32). Furthermore, social and political aspects seeped into the research, and it was extremely significant that ten people entirely copied the statement of Ken Saro-Wiwa quoted on a panel of the ISM "to take away the resources of the people and refuse to give them anything in return is to subject them to slavery" on their handouts without daring to comment on it freely in front of the Governor's spokesman: it was sad evidence that, as one of the students wrote down, "we are still slaves, only in a different way". They are possibly still enslaved by their politics, or by the ashes of the civil war, or even by the slavery of their ancestors. The unwelcome and absolutely inappropriate presence of political personalities in the meeting; the consequent silence in the classrooms during the free debate; the praise for the ISM and the resignation of the students who took for granted the paucity of their National Slavery Museum; the expressed desire to have the Liverpool Museum in Luanda and the unexpressed bravery in asking why their National Slavery Museum is not equipped like the Liverpool one - all these signals suggested a sort of enslavement of the minds lingering in the classrooms. Present-day Angola perfectly embodies the enduring effects of five centuries of slavery oppression: the endemic political corruption; the unfair distribution of wealth; the natural resources devoured by multinational corporations; the population manipulated by the dominant political party and by Western channels of entertainment aimed merely at distracting people from its controversial and problematic reality.

In remembering a guilty, mortifying past, present-day museums' social mission is not merely the individualization of the perpetrators, nor the commemoration of the victims, nor the creation of self-reflective visitors: present-day museums have to generate a new "historical awareness, that might form the basis for a movement towards social justice" (Wallace 65). A study conducted in 2017 within the NAAU project (National Awareness, Attitudes, and Usage Study) revealed that museums, besides being considered highly credible sources of information, are also trusted as official and unquestionable entities: in the USA, museums are more credible than daily newspapers, NGOs and federal agencies (Dilenschneider). People interviewed in the same study also claimed that museums should suggest or recommend certain behaviours or ways for the general public to support their causes and missions - thus confirming the increasing importance of post-museums as forums for community engagement.

The past needs to be discovered, and discussed, as do its relations to present-day inequalities and oppressions; meaningful connections between human rights violations of the past and economic and social inequalities of today have to be considered: on $25^{\text {th }}$ March 2020, in his message for the International Day of Remembrance of the Victims of Slavery and the Transatlantic Slave Trade - which has been celebrated annually since 2007 - the UN Secretary-General António Guterres called for the dismantling of racist structures and the reforming of racist institutions. Guterres recalled how the transatlantic slave trade seeded deep inequalities within societies and how the descendants of enslaved people are nowadays experiencing enduring acts of intolerance, prejudice and discrimination and facing social and economic inequality. The theme for this year's International Day of Remembrance was in fact “Confronting Slavery's Legacy 
of Racism Together", i.e. an urgent call to reflect on connections between past and present - post-museums, as places of encounter par excellence, have to be ready to take up the call.

More voices have to be heard - voices from the ground, marginal voices, voices who speak uncommon languages - and much more reflection has to be stimulated. An encouragement to the expression of multiple minor voices can be the digital translation of the ISM itself: if the ISM were virtually visitable from all over the world and translated into different languages, minor voices would be recognized, and would finally find a place to read, to be read, and to react by offering their perspective, so far unheard. The above-mentioned case study itself implied a translation: the plain English used in the panels of the ISM exhibition was translated into Portuguese, a European language shared nationally, but not ethnically. An essential choice, yet one which almost embodies the perpetuation of a colonial action. Only by including the unheard voices may the tragedy of slavery finally be translated: for example, reading the history of slavery told in the language of the oppressed instead in that of the oppressors, or recalling the atrocious facts through songs and drumbeats instead of through motionless display cases. This action of reversing the historical narrative has been successfully taken by the Digital Museum of African and Afro-Brazilian Memory, a digital museum aiming at preserving and disseminating the knowledge and memory of African art and culture and the heritage of the Global South in general (Sansone 261). The Digital Museum presents itself as a democratizing place, where constructions of identity are constantly produced, marginalized groups are given voice and recognized, and local, national and international connections are created. In view of its technological nature, it is a free museum, accessible, dynamic and interactive.

If language, instead of being a mere part of a culture, is also a vehicle which reflects the culture itself, then the act of translation can wait, and be replaced by the act of restitution.

\section{[Bibliography]}

Anderson, Benedict. Imagined Communities: Reflections on the Origins and Spread of $\mathrm{Na}$ tionalism. London: Verso, 2016.

Appadurai, Arjun. Modernity at Large: Cultural Dimensions of Globalization. Minneapolis, London: University of Minnesota Press, 1996.

Asad, Talal. "The Concept of Cultural Translation in British Social Anthropology". Writing Culture. The Poetics and Politics of Ethnography. Eds. James Clifford and George E. Marcus. Berkeley: University of California Press, 1968. 141-64.

Bachmann-Medick, Doris. "Meaning of Translation in Cultural Anthropology". Translating Others. Vol.1. Ed. Theo Hermans, Manchester: St. Jerome Publishing, 2006. 33-42. Bal, Mieke. "Telling, Showing, Showing Off”. Critical Inquiry, 18.3 (Spring 19920: 556-94. Barthes, Roland. "From Work to Text”. Image/Music/Text. London: Fontana, 1977. 155-164. Bassil, Noel Noah. "The Legacy of Colonial Racism in Africa”. AQ: Australian Quarterly 77.4 (2005): 27-32. 
Benjamin, Richard. "Museums and the Political Landscape”, ISUU, Museum Identity Magazine 2, 2009: 30-37.

Besterman, Tristan. "Museum Ethics”. A Companion to Museum Studies. Ed. Sharon Macdonald. Oxford: Blackwell, 2006. 431-41.

Bhabha, Homi K. The Location of Culture. London: Routledge, 1994.

Carbonell, Bettina Messias. Museum Studies: an Anthology of Contexts. Malden, MA: Blackwell Publishing, 2004.

Clifford, James. "Museums as Contact Zones”. Representing the Nation: A Reader - Histories, Heritage and Museums. Eds. David Boswell and Jessica Evans. London: Routledge, 1999. 435-57.

---. The Predicament of Culture: Twentieth-century Ethnography, Literature, and Art. Cambridge, Mass.: Harvard University Press, 1998.

---. “Traveling Cultures”. Cultural studies. Eds. Lawrence Grossberg, Cary Nelson and Paula A. Treichler. New York, London: Routledge, 1992. 96-122.

Dilenschneider, Colleen. People trust museums more than newspapers. Here is why that matters right now. IMPACTS Experience. Web. 26 Apr. 2017. https://www.colleendilen. com/2017/04/26/people-trust-museums-more-than-newspapers-here-is-why-thatmatters-right-now-data/

Duncan, Carol. Civilising Rituals: Inside Public Arts Museums. London: Routledge, 1995. Ficarra, Alessandra. “(Un)Translatable Slavery: the Case of the International Slavery Museum, Liverpool”. La Questione Romantica. 7.1-2. Special Issue: Edward Rushton's Bicentenary. Eds. Paul Baines, Lilla Maria Crisafulli, Franca Dellarosa, Greg Lynall. Naples: Liguori Editore, 2017: 121-137.

Foucault, Michel. The Archaeology of Knowledge. London, New York: Routledge, 1972. Hira, Sandew. "Decolonizing the Mind: The Case of the Netherlands". Human Architecture: Journal of the Sociology of Self-Knowledge 10.1 (2012): 53-68.

Hooper-Greenhill, Eilean. Museums and the Interpretation of Visual Culture. London, New York: Routledge, 2000.

Ingold, Tim. “The Art of Translation in a Continuous World”. Beyond Boundaries: Understanding, Translation and Anthropological Discourse. Ed. Gísli Pálsson. Oxford: Berg, 1993. 210-30.

MacGaffey, Wyatt. "Structural Impediments to Translation in Art”. Translating Cultures: Perspectives on Translation and Anthropology. Eds. Paula G. Rubel and Abraham Rosman. Oxford: Berg, 2003. 260-61.

Miller, Joseph Hillis. "Border Crossing, Translation Theory: Ruth". The Translatability of Cultures: Figurations of the Space Between. Eds. Sanford Budick and Wolfgang Iser. Stanford, Calif.: Stanford University Press, 1996. 316-37.

Ribeiro, Djamila. O que é lugar de fala? Belo Horizonte: Letramento, 2017.

Rushdie, Salman Ahmed. "Imaginary Homelands”. London Review of Books 4.18 (October 1982): 18-19.

Sansone, Livio. “The Dilemmas of Digital Patrimonialization: The Digital Museum of African and Afro-Brazilian Memory”. History in Africa 40 (2013): 257-273. 
Silverstone, Roger. "Heritage as Media: Some Implications for Research”. Heritage Interpretation. Vol. 2: The Visitor Experience. Ed. David L. Uzzell. London: Belhaven Press, 1989. 138-48.

Simine, Silke Arnold-de. Mediating Memory in the Museum. Trauma, Empathy, Nostalgia. London: Palgrave Macmillan, 2013.

Sturge, Kate. Representing Others: Translation, Ethnography and the Museum. Manchester: St. Jerome Publishing, 2007.

Trouillot, Michel-Rolph. Silencing the Past: Power and the Production of History. Boston: Beacon Press, 1995.

Wallace, Elizabeth Kowaleski. The British Slave Trade and Public Memory. New York, Chichester: Columbia University Press, 2006.

\section{[Address]}

Ph.D., Assegnista di Ricerca in Lingua e Traduzione Inglese

Dipartimento di Culture, Educazione e Società (DICES)

Università della Calabria

ITALY

alessandra.ficarra@unical.it

Alessandra Ficarra attained her Ph.D. in Translation Studies from the University of Bari Aldo Moro, Italy, with a work titled "The (un) translatability of Culture: Memory, Identity and Power in the Language of Slavery Museums", conducting her Ph.D. research at the University of Manchester, the University of Liverpool and the International Slavery Museum in Liverpool, England, and carrying out fieldwork in three provinces of Angola. Her research interests include human rights issues, post-colonial identity and museum representations. Currently, she is teaching English at the Università degli Studi della Calabria, involving her students in group-work activities and seminars on Ethical Dark Tourism, and she is a Research Fellow at the Department of Culture, Education and Society of the same university. 